KOMPARTEMEN: JURNAL ILMIAH AKUNTANSI

Maret 2020, Volume XVIII, No 1, 13-21

\title{
PENGARUH GOOD CORPORATE GOVERNANCE TERHADAP KINERJA KEUANGAN PADA SEKTOR BARANG KONSUMSI DI BEI
}

\author{
Okta Setiawan $^{1}$, Iwan Setiadi ${ }^{2}$ \\ Institut Teknologi dan Bisnis Ahmad Dahlan Jakarta ${ }^{1,2}$ \\ oktaokta4@yahoo.com ${ }^{1}$
}

\begin{abstract}
The purpose of this study is to examine the effect of good corporate governance (GCG) on financial performance using the measurement of return on assets (ROA). The sample of this research is the manufacturing companies in the consumer goods sector which are listed on the Indonesia Stock Exchange. The data collection technique used in this study was purpose sampling, which consisted of 154 companies. The analysis of this study uses multiple linear regression analysis methods. The results showed that GCG consisting of independent commissioners had a significant positive effect on financial performance (ROA), independent audit committee had no effect on (ROA), institutional ownership had a significant positive effect on financial performance (ROA), and managerial ownership financial performance (ROA).
\end{abstract}

Keywords: GCG, independent commissioner, independent audit committee, institutional ownership, managerial ownership, and financial performance.

\begin{abstract}
ABSTRAK
Tujuan dari penelitian iniadalah untuk menguji pengaruh good corporate governance (GCG) terhadap kinerja keuangan dengan mengunakan pengukuran return on aseets (ROA). Sampel penelitian ini adalah perusahaan manufaktur sektor barang konsumsi yang terdaftar di Bursa Efek Indonesia. Teknik pengumpulan data yang digunakan dalam penelitian ini adalah purpose sampling, yang terdiri dari 154 perusahaan. Analisispenelitianinimenggunakan metode analisis regresi linear berganda. Hasil penelitian menunjukan bahwa GCG yang terdiri dari komisaris independen berpengaruh positif signifikan terhadap kinerja keuangan (ROA), komite audit independen tidak berpengaruh terhadap kinerja keuangan (ROA), kepemilikan institusional berpengaruh positif signifikan terhadap kinerja keuangan (ROA), dan kepemilikan manajerial berpengaruh terhadap kinerja keuangan (ROA).

Kata Kunci: GCG, komisaris independen, komite audit independen, kepemilkan institusional, kepemilikan manajerial, dan kinerja keuangan.

\section{PENDAHULUAN}

Tujuan dari penelitian ini untukmengujipengaruh good corporate governance terhadap kinerja keuangan. Good corporate governance dalam penelitian ini terdiri dari komisaris independen, komite audit independen, kepemilikan institusional, dan kepemilikan manajerial. Komisaris independen diukur dengan proporsi jumlah komisaris independen dibagi jumlah komisaris. Komite audit independen diukur dengan proporsi jumlah komite audit independen dibagi jumlah komite audit. Kepemilikan manajerial diukur dengan jumlah kepemilikan manajer
\end{abstract}


dibagi saham beredar, dan kepemilikan institusional diukur dengan jumlah kepemilikan institusi dibagi saham beredar. Sedang kinerja keuangan diukur dengan proksi return on assets.

Penelitian ini didasari dengan adanya fenomena-fenomena tentang kurangnya penerapan $G C G$ dengan baik yang berdampak pada kinerja keuangan. Kasus PT Mayora Indah Tbk. Yang merupakan produsen makanan dan minuman, pada akhir juli kuartal I tahun 2019, mencatatkan margin bersih 7,75\%, kemudian dilaporkan pada kuartal II-2019, margin bersih perusahaan berada di kisaran 6,7\%, sehingga margin bersih kurtal I dan kuartal II 2019 mengalami penurunan sebesar 1,05\% (www.cnbcindonesia.com, 2019). Fenomena ini memperkuat gagasan bahwa penerapan good corporate governance mempengaruhi baik dan buruknya kinerja dan laporan keuangan di suatu perusahaan (Sutedi, 2012). Fenomena tersebut memperlihatkan bahwa perusahan belum sepenuhnya menerapkan GCG dengan baik dan berdampak pada laporan dan kinerja keuangan yang kurang baik.

Fenomena kedua yang mendasari penelitian ini adalah terjadi pada Kasus pada PT. Tiga Pilar Sejahtera Food Tbk yang berkaitan dengan buruknya kinerja keuangan perusahaan yang merugikan calon investor. Pada kasus ini PT. Tiga Pilar Sejahtera Food Tbk (AISA) menghentikan bisnis beras pasca kasus hukum yang menimpa pada pertengahan tahun lalu membuat kinerja perusahaan memburuk. Berdasarkan laporan keuangan AISA per 31 Desember 2017, kinerja keuangan AISA turun drastis. Pendapatan AISA tahun 2017 Rp 4,29 triliun, dari yang sebelumnya 5,35 triliun, maka terjadi seleisih pendapatan sebesar 24,8\% dibandingkan periode sama tahun lalu. Hingga akhir 2017, AISA harus mengalami kerugian bersih sebesar Rp 551,9 miliar. Padahal, per 31 Desember 2016, AISA masih mencetak laba bersih senilai Rp 581 miliar (kontan.co.id, 2017). Hal ini menjelaskan buruknya kinerja keuangan perusahaan akibat perusahaan tidak menerapkan prinsip-prinsip goood corporate governance secara kongkret yang diantaranya adalah kurangnya transparansi terhadap publik.

Komisaris independen dapat meningkatkan fungsi pengawasan pada perusahaan. Dewan komisaris independen merupakan komisaris yang tidak ada hubungan keluarga atau hubungan bisnis dengan direksi maupun pemegang saham (Rachmad, 2012). Adanya dewan komisaris independen, maka kepentingan pemegang saham baik mayoritas maupun minoritas tidak diabaikan, karena komisaris independen lebih bersikap netral terhadap keputusan yang dibuat oleh manajer (Puspitasari dan Ernawati, 2010). Komisaris independen dapat membantu perusahaan menghindari ancaman-ancaman dari luar sehingga tetap bisa mempertahankan sumber daya perusahaan agar mendapatkan keuntungan yang lebih, yang nantinya dapat meningkatkan kinerja keuangan (ROA).

Komite audit independen memiliki peran penting memelihara dan membantu dewan komisaris dalam proses penyusunan laporan keuangan agar tercipta sistem pengawasan perusahaan yang memadai serta pelaksanaan good corporate governance. Komite audit melakukan pemeriksaan dan pengawasan tentang proses pelaporan keuangan dan kontrol internal sehingga akan meminimalisir adanya keuntungan sepihak dari pihak manajemen. Adanya komite audit akan memberikan pengawasan pada perusahaan serta menjamin pengelolaan perusahaan yang dapat mendukung peningkatan kinerja keuangan (Handayani, 2018).

Kepemilikan institusional memiliki arti penting dalam memonitor manajemen, karena dengan adanya kepemilikan institusional mampu mendorong peningkatan pengawasan yang lebih 
optimal. Proporsi pada kepemilikan istitusional yang besar dapat meningkatkan usaha pengawasan oleh pihak institusi sehingga dapat menghalangi perilaku oportunistik manajer dan dapat membantu pengambilan keputusan perusahaan, sehingga dapat meningkatkan kinerja keuangan perusahaan yang diukur dengan ROA (Candradewi dan Sedana 2016).

Kepemilikan manajerial merupakan salah satu aspek corporate governance yang merupakan manajer yang memiliki saham perusahaan (Aprianingsih, 2016). Kepemilikan manajerial dapat menyeimbangkan antara kepentingan manajer dengan pemegang saham yang kemudian dapat menghasilkan mekanisme yang dapat mengurangi suatu masalah keagenan antara manajer dengan pemegang saham. Menurut Jensen dan Meckling (1976) dalam Widyati (2013) kepemilikan saham oleh manajer dapat mensejajarkan kepentingan manajer dan pemegang saham karena dengan memiliki saham perusahaan, manajer akan merasakan langsung manfaat dari setiap keputusan yang diambilnya, begitu pula bila terjadi kesalahan maka manajer juga akan menanggung kerugian sebagai salah satu konsekuensi kepemilikan saham. Hal ini merupakan insentif bagi manajer untuk upaya meningkatkan kinerja perusahaan.

Penelitian ini merupakan pengembangan hasil riset dari beberapa penelitian mengenai pengaruh good corporate governance terhadap kinerja keuangan yang menunjukan hasil yang berbeda-beda. Perbedaan penelitian ini dengan penelitian sebelumnya terdapat pada variabel independen, periode tahun penelitian, dan sektor perusahaan, peneliti menggunakan komite audit independen, sedangkan penelitian-penelitian sebelumnya tidak menggunakan komite audit independen sedangkan untuk objek penelitian ini di ambil dari perusahaan manufaktur sektor barang konsumsi yang terdaftar di BEI periode 2012-2018.

\section{LITERATUREREVIEW}

\section{Teori Keagenan}

Teori keagenan menjelaskan tentang hubungan yang terjadi antara principle dengan agent. Pihak principle atau pemilik akan memberikan wewenang kepada pihak agent atau pengelola dalam menjalankan usahanya dengan harapan bahwa agent akan menjalankannya dengan baik sehingga dapat memaksimalkan nilai perusahaan yang sesuai dengan tujuan principle. Berdasarkan hal tersebut, principle memberikan wewenang kepada agent untuk dapat mengelola dan mengambil suatu keputusan atas nama principle. Adanya pemisahan antara kepemilikan dengan pengelola menyebabkan timbulnya suatu permasalahan yang disebut sebagai masalah agent. Namun, dapat diterapkan suatu mekanisme untuk mengurangi adanya suatu kesempatan bagi manajer melakukan tindakan yang merugikan principle. Mekanisme yang dapat meminimalisir permasalahan tersebut terdiri dari dua mekanisme kontraktual yaitu monitoring dan bonding (Jensen dan Meckling 1976, dalam Handayani, 2018).

\section{Komisaris Independen}

Dewan komisaris independen merupakan bagian dari corporate governance. Dewan komisaris merupakan mekanisme pengendalian internal tertinggi yang memiliki tugas untuk mengawasi tindakan manajemen puncak. Dewan komisaris bertanggung jawab untuk memastikan bahwa perusahaan melaksanakan good corporate governance. Sesuai dengan penelitian yang dilakukan oleh Handayani (2018), Sarafina dan Saifi (2017), canradewi dan Sedana (2016) dan 
widyati (2013), mendapatkan hasil bahwa komisaris independen berpengaruh positif terhadap kinerja keuangan. Berdasarkan Uraian di atas dapat diambil hipotesis sebagai berikut :

H1 : Komisaris Independen berpengaruh positif signifikan terhadap kinerja keuangan (ROA)

\section{Komite Audit Independen}

Komite audit merupakan suatu komite yang bekerja secara profesional dan independen yang dibentuk oleh dewan komisaris, dengan demikian tugasnya adalah membantu dan memperkuat fungsi dewan komisaris dalam menjalankan fungsi pengawasan. Komite audit diukur dengan menggunakan jumlah komite audit. Jumlah komite audit yang semakin banyak akan memberikan kontrol yang lebih baik terhadap proses akuntansi dan keuangan perusahaan yang pada akhirnya akan memberikan pengaruh positif terhadap kinerja keuangan perusahaan. Dengan demikian, adanya komite audit maka kinerja perusahaan akan semakin terkontrol dan terkendali dalam menjalankan tugasnya (Widyati, 2013). Sesuai Penelitian yang dilakukan Aprinita (2016), Widyati (2013), Ayu Nur Aini et all (2017), Yulianawati (2014), dan Astuti (2019), mendapatkan hasil bahwa komite audit berpengaruh negatif terhadap kinerja keuangan. Berdasarkan uraian diatas dapat diambil hipotesis sebagai berikut :

\section{H2 : Komite Audit Independen berpengaruh positif terhadap kinerja keuangan (ROA) Kepemilikan Institusional}

Kepemilikan institusional adalah kepemilikan saham perusahaan oleh institusi keuangan seperti perusahaan asuransi, bank, dana pensiun, dan investment banking (Widyati, 2013). Sesuai penelitian yang dilakukan Susanti (2013), Handayani (2018), Widyati (2013), Yulianawati (2014), dan Candradewi dan Sedana (2016), mendapatkan hasil bahwa kepemilikan institusional berpengaruh positif terhadap kinerja keuangan. Berdasarkan uraian diatas dapat diambil hipotesis sebagai berikut :

\section{H3 : Kepemilikan institusional berpengaruh positif signifikan terhadap kinerja keuangan (ROA)}

\section{Kepemilikan Manjerial}

Kepemilikan manajerial merupakan pemilik perusahaan sekaligus menjadi pengelola perusahaan. Semakin besar proporsi kepemilikan manajerial maka akan semakin kecil peluang terjadinya konflik, karena jika pemilik bertindak sebagai pengelola perusahaan maka dalam pengambilan keputusan akan sangat berhati-hati agar tidak merugikan perusahaan. Apabila kepemilikan manajerial kecil maka semakin sedikit pula pemegang saham yang terlibat dalam pengelolaan perusahaan, sehingga semakin tinggi munculnya masalah keagenan dikarenakan perbedaan kepentingan yang semakin besar (Candradewi dan Sedana, 2016). Sesuai penelitian yag dilakukan Wahyuni Agustina, Gede Adi Yuniarta, Ni Kadek Sinarwati (2015), dan Candradewi dan Sedana (2016), mendapatkan hasil bahwa kepemilikan manajerial berpengaruh positif terhadap kinerja keuangan. Berdasarkan uraian diatas dapat diambil hipotesis :

H4 : Kepemilikan Manajerial berpengaruh positif signifikan terhadap kinerja keuangan (ROA).

\section{METODE PENELITIAN}


Sampel dalam penelitian ini adalah perusahaan manufaktur yang terdaftar di Bursa Efek Indonesia (BEI) pada periode tahun2012-2018. Teknik pengumpulan data pada penelitian ini menggunakan data sekunder, berupa laporan tahunan perusahaan manufaktur yang listing di BEI. Data sekunder diperoleh darisitus www.idx.co.id dan dari website masing-masing perusahaan sampel.

Variabel dependen dalam penelitian ini adalah kinerja keuangan yang di proksikan dengan ROA.

$$
\text { ROA }=\frac{\text { Laba Bersih Setelah Pajak }}{\text { Total Asset }}
$$

Variabel independen dalam penelitian ini terdiri dari Komisaris independenYang diukur dengan jumlah komisaris independen di bagi dengan jumlah komisaris. Komite audit independen diukur dengan jumlah komite audit independen dibagi dengan jumlah komite audit. Kepemilikan Institusional diukur dengan jumlah kepemilikan pihak institusi dibagi dengan saham beredar. Kepemilikan Manjerial diukur dengan jumlah saham yang dimiliki pihak manajerial dibagi dengan saham beredar.

Penelitian ini menggunakan metode pengambilan sampel secara purposive sampling atau dengan berdasarkan pada kriteria-kriteria tertentu dengan tujuan untuk mendapatkan sampel yang sesuai dengan kriteria yang telah di tentukan. Jumlah perusahaan sektor barang konsumsi yang akan dijadikan sampel dari tahun 2012-2018 sebanyak 154 yang berasal dari 22 perusahaan sektor baranag konsumsi yang sudah sesuai dengan kriteria.

\section{HASIL PENGUJIAN HIPOTESIS DAN PEMBAHASAN}

Tabel.1 memberikangambaranstatistikdeskriptifdari setiapvariabel khususnya minimum, maksimum, rata-rata, standar deviasi, dan jumlah pengamatan.

\begin{tabular}{l|r|r|r|r|r}
$\begin{array}{l}\text { Tabel 1. Statistik Deskriptif } \\
\text { Descriptive Statistics }\end{array}$ & & \\
& $N$ & Minimum & Maximum & Mean & Std. Deviation \\
\hline & 154 &, 33 &, 83 &, 4170 &, 11378 \\
\hline $\begin{array}{l}\text { Proporsi Dewan } \\
\text { Komisaris }\end{array}$ & 154 &, 25 &, 50 &, 3329 &, 02954 \\
\hline Proporsi Komite Audit & 154 &, 33 &, 99 &, 7644 &, 16574 \\
\hline Kepemilikan Institusional & 154 &, 00 &, 76 &, 0536 &, 14896 \\
\hline Kepemilikan Manajerial & 154 &, 97 & 92,10 & 14,7002 & 14,06909 \\
\hline Return On Asset & 154 & & & & \\
\hline Valid N (listwise) & & & & & \\
\hline
\end{tabular}

\section{Uji Asumsi Klasik}

Uji asumsi klasik dalam penelitian ini terdiri dari uji Kolmogorov-Smirnov untuk menguji normalitas data secara statistik, uji autokorelasi dengan menggunakan Durbin Watson statistik, uji heterosedastisitas dengan menggunakan metode chart (diagram Scatterplot) dan uji multikolinieritas dengan menggunakan Variance Inflation Factors (VIF). Data yang di oleh normal, tidak terjadi multokolinieritas antar variabel independen, tidak terdapat adanya heteroskedastisitas dan tidak terdapat gejala autokorelasi. 


\section{Hasil Uji Kelayakan Model (Godness of Fits)}

Hasil uji koefisien determinasi $\left(\mathrm{R}^{2}\right)$ yang terlihat pada Tabel 2 menunjukkan koefisien determinasi (Adjusted $\mathrm{R}^{2}$ ) adalah 0,218 atau $21,8 \%$ ini berarti bahwa variabel independen memiliki pengaruh terhadap variabel dependen sebesar21,8\%. Hasiluji $F$ pada Tabel 2 menunjukkan semua variabel independen secara simultan mempengaruhi variable dependen.

\section{Tabel 2}

\section{Hasil Pengujian Langsung}

\begin{tabular}{|c|c|c|c|}
\hline Variabel & Predicted Sign & Coefficient & p-value \\
\hline Intercept & & $-3,684$ & 0,209 \\
\hline Sqrt_DKI & + & 6,808 & 0,000 \\
\hline Sqrt_KAI & + & 1,363 & 0,770 \\
\hline Sqrt_KI & + & 2,495 & 0,023 \\
\hline Sqrt_KM & - & $-0,785$ & 0,020 \\
\hline
\end{tabular}

Adj. $R^{2}$

0,218

\begin{tabular}{lll} 
& F-Statistic & 11,660 \\
& Prob $($ F-statistic $)$ & $\mathbf{0 , 0 0 0} * * *$ \\
\cline { 3 - 3 }$N$ & 153 & \\
\cline { 2 - 3 } & $*, * *, * * *$ menunjukan koefisien signifikan pada 0,$1 ; 0,05 ; 0,01$
\end{tabular}

Berdasarkan Tabel 2, variable dewan komisaris independent memiliki nilai koefisien regresi sebesar 6,808 dengan signifikansi sebesar 0,000<0,05sehingga hipotesis 1 diterima.Hasil penelitian ini konsisten dengan hasil penelitian sebelumnya Yuliani (2018), Handayani (2018), Sarafina dan Saifi (2017), canradewi dan Sedana (2016) dan widyati (2013) yang membuktikan bahwa komisaris independen mempunyai pengaruh positif terhadap kinerja keuangan. Hal ini dapat dijelaskan, semakin besar proporsi dewan komisaris independen yang berasal dari luar perusahaan dengan keahlian dan pengalaman yang beragam akan memungkinkan dapat meningkatkan kemampuan dewan komisaris dalam melakukan pengawasan. Keberadaan komisaris independen dimaksudkan untuk menciptakan iklim yang lebih objektif dan independen, menjaga fairness serta mampu memberikan keseimbangan antara kepentingan pemegang saham mayoritas dan perlindungan terhadap kepentingan pemegang sahama minoritas, bahkan kepentingan para stakeholder lainnya.

Berdasarkan tabel 2 variabel KAI memiliki nilai $t_{\text {hitung }}$ sebesar 1,363 dengan nilai signifikansi 0,770. Nilai signifikansi lebih besar dari 0,05 menunjukan variabel KAI tidak berpengaruh terhadap ROA. Dengan demikian H2 ditolak. Hasil penelitian ini tidak sejalan dengan hasil penelitian sebelumnya Aprinita (2016), Widyati (2013), Ayu Nur Aini et all (2017), Yulianawati (2014), dan Astuti (2019), Maharani (2018), Handayani (2018), Sarafina dan Saifi (2017), Widyastuti (2017), dan Aprianingsih (2016) yang membutikan bahwa proporsi komite audit independen berpengaruh terhadap return on asset. Komite audit yaitu merupakan suatu komite yang bekerja secara profesional dan independen yang dibentuk oleh dewan komisaris, dengan demikian tugasnya adalah membantu dan memperkuat fungsi dewan komisaris dalam 
menjalankan fungsi pengawasan. Jumlah komite audit yang semakin banyak akan memberikan kontrol yang jauh lebih baik terhadap proses akuntansi dan keuangan perusahaan yang pada akhirnya akan memberikan pengaruh positif terhadap kinerja keuangan perusahaan. Dengan demikian, adanya komite audit maka kinerja perusahaan akan semakin terkontrol dan terkendali dalam menjalankan tugasnya.

Berdasarkan tabel 2 variabel KI memiliki nilai $t_{\text {hitung }}$ sebesar 2,495 dengan nilai signifikansi 0,023. Nilai Signifikansi yang lebih kecil 0,05 tersebut menunjukan variabel KI berpengaruh positif signifikan terhadap ROA. Dengan demikian H3 diterima. Hasil penelitian ini menunjukkan konsisten dengan hasil penelitian sebelumnya Susanti (2013), Handayani (2018), Widyati (2013), Yulianawati (2014), dan Candradewi dan Sedana (2016), mendapatkan hasil bahwa kepemilikan institusional berpengaruh positif terhadap kinerja keuangan.Eriandani (2013) menjelaskan bahwa kepemilikan institusional merupakan salah satu faktor yang mampu mempengaruhi kinerja perusahaan. Jika investor institusional banyak maka akan meningkatkan pengawasan kinerja manajemen menjadi lebih tinggi karena pihak institusi memiliki divisi investasi sendiri sehingga tingkat pengawasan akan lebih ketat dan menghalangi perilaku opportunistic manajer yang menimbulkan kepentingan antara pengelola dengan pemilik dapat sejalan dan menimbulkan dampak positif terhadap kinerja perusahaan.

Berdasarkan tabel 2 variabel KM memiliki nilai $t_{\text {hitung }}$ sebesar -0,785 dengan nilai signifikansi 0,020. Nilai signifikansi lebih kecil dari 0,05 menunjukan variabel KM berpengaruh negatif signifikan terhadap ROA. Dengan demikian H4 diterima. Hasil penelitian ini konsisten dengan hasil penelitian sebelumya Handayani (2018), Rizki, Zahara, dan Santi (2019), dan Aprianingsih (2016) bahwa kepemilikan manajerial berpengaruh negatif terhadap kinerja keuangan. Kepemilikan manajerial yaitu merupakan pemilik perusahaan sekaligus menjadi pengelola perusahaan. Semakin besar proporsi kepemilikan manajerial maka semakin kecil peluang terjadinya konflik, karena jika pemilik bertindak sebagai pengelola perusahaan maka dalam pengambilan keputusan akan sangat berhati-hati agar tidak merugikan perusahaan. Apabila kepemilikan manajerial kecil maka menunjukkan semakin sedikit pula pemegang saham yang terlibat dalam pengelolaan perusahaan, sehingga semakin tinggi munculnya masalah keagenan dikarenakan perbedaan kepentingan yang semakin besar (Candradewi dan Sedana, 2016).

\section{KESIMPULAN, KETERBATASAN DAN SARAN}

Berdasarkan hasil analisis yang telah dilakukan, dapat diambil kesimpulan bahwa komisaris independen berpengaruh terhadap return on assets, komite audit independen tidak berpengarug terhadap return on assets, kepemilikan institusional berpengaruh positif signifikan terhadap return on assets, dan kepemilikan manajerial berpengaruh negatif signifikan terhadap return on asssets. Keterbatasan dalam penelitianiniadalah peneliti belum menggunakan semua proksi corporate governance, sehingga belum dapat mengeneralisasi penerapan corporate governance di perusahaan. Untuk penelitianselanjutnyapenelitian ini diharapkan bisa menjadi gambaran serta untuk menambah referensi, wawasan, memberikan tambahan pengetahuan dan diharapkan dapat dijadikan bahan untuk pengembangan penelitian selanjutnya, dengan tema dan variabel yang berbeda agar mampu menciptakan penelitian-penelitian baru yang lebih baik. Bagi 
perusahaan Perusahaan sebaiknya melaksanakan dan menerapkan corporate governance secara baik, benar dan sungguh-sungguh sehingga tidak merugikan para investor dalam berinvestasi.

\section{Daftar Pustaka}

Aini, Ayu Nur., Edi., dkk. 2017. "Pengaruh Kepemilikan Institusional, Proporsi Dewan Komisaris Independen, Komite Audit, Struktur Modal, Ukuran Perusahaan Dan Leverage Terhadap Kinerja Keuangan." Jurnal Ekonomi-Akuntansi. Universitas Pandanaran, Semarang

Aprianingsih, Astri .2016. 'Pengaruh Penerapan Good Corporate Governance, Struktur Kepemilikan, dan Ukuran Perusahaan Terhadap Kinerja'

Aprinita, 2016. Pengaruh Good Corporate Governance Terhadap Kinerja Keuangan Sektor Consumer Goods Yang Terdaftar Di Bursa Efek Indonesia. Jurnal Bisnis dan Manajemen, Vol. 52/No.11 : 32-53

Astuti Ira Tri, 2019. Pengaruh Good Corporate Governance Terhadap Kinerja Keuangan, Studi Empiris Perusahaan Makanan dan Minuman di Bursa Efek Indonesia tahun 20142017, Manajemen Fakultas Ekonomi Dan Bisnis. UMS.

Candradewi, I., \& Sedana, I. B. P. (2016). Pengaruh Kepemilikan Manajerial, Intitusional dan Dewan Komisaris Independen Terhadap Return On Asset. EJurnal Manajemen Unud, 5(5), 3163-3190.

Ghozali, Imam. 2018. Aplikasi Analisis Multivariate dengan Program IBM SPSS 25 Edisi 9. Semarang: Universitas Diponegoro.

Handayani, 2018. Pengaruh GCG Terhadap Kinerja Keuangan Perusahaan Pada Perusahaan Manufaktur di BEI, Skripsi Sarjana, STIE Perbanas Surabaya.

https://investasi.kontan.co.id/news/banyak-tertimpa-masalah-bagaimana-kinerja-keuangan-tigapilar-aisa-di-2018

https://www.cnbcindonesia.com/market/20190722113510-17-86561/laba-mayora-tumbuh-10tapi-sayang-marjin-laba-turun

Jensen, Michael C. Dan Willian H. Mechling. (1976). Theory of the Firm: Managerial Behavior, Agency Costs and Ownership Structure. Journal of Financial Economics, Vol. 3, No.4, pp.305-360.

Maharani, 2018. Pengaruh Good Corporate Governance dan Ukuran Perusahaan Terhadap Kinerja Keuanagan Perusahaan Property dan Real Estate yang Terdaftar di Bursa Efek Indonesia Tahun 2015-2017, Skripsi, Universitas Islam Indonesia, Yogyakarta.

Puspitasari, Filia and Endang Ernawati. 2010. Pengaruh Mekanisme Corporate Governance Terhadap Kinerja Keuangan Badan Usaha. Jurnal Manajemen Teori dan Terapan, 3 (2), pp: 189-215

Rachmad, Anas Ainur. 2012. Pengaruh Penerapan Corporate Governance Berbasis Karakteristik Manajerial pada Kinerja Perusahaan Manufaktur.Skripsi Fakultas Ekonomi Universitas Udayana

Rizka, Zahara, Santi, 2019. Pengaruh Intellectual Capital dan Mekanisme Corporate Governance Terhadap Kinerja Keuangan pada Perusahaan Manufaktur yang terdaftar di Bursa Efek Indonesia Periode 2015-2017, Akuntansi dan Manajemen Vol.14, No.1 : 58-81

Salsabila Sarafina, Muhammad Saifi. 2017. Pengaruh GCG Terhadap Kinerja Keuangan dan Nilai Perusahaan (Studi pada Badan Usaha Milik Negara (BUMN) yang Terdaftar di Bursa Efek Indonesia Periode 2012-2015) Jurnal Administrasi vol. 50 no.2, Univeristas Brawijaya Malang. 
Susanti. 2013. Pengaruh Pelaksanaan Good Corporate Governance, Kepemilikan Institusional, dan Leverage Terhadap Kinerja Keuangan (Studi pada Perusahaan Manufaktur di Bursa Efek Indonesia Pada tahun 2009 - 2011), Skripsi Sarjana, Universitas Negeri Padang.

Widyastuti, 2017. Pengaruh Good Corporate Governance Terhadap Kinerja Keuangan Perusahaan (Studi Empiris Perusahaan Farmasi di Bursa EfekIndonesia Periode2013-2016). Skripsi Universitas Muhamadiyah Surakarta.

Widyati, Maria Fransisca. 2013. Pengaruh dewan direksi, komisaris independen, komite audit, Kepemilikan manajerial dan kepemilikan institusional Terhadap kinerja keuangan. Jurnal Ilmu Manajemen, Vol. 1 No.1

Yulianawati, Ika. 2014. Pengaruh Good Corporate Governance dan Leverage terhadap Kinerja Keuangan Perusahaan Manufaktur yang Terdaftar di BEI Periode 2011-2012. Universitas Muhamadiyah Surakarta. 